\title{
PENGARUH TERAPI HIPNOSIS TERHADAP KADAR GULA DARAH PADA PASIEN DM TIPE 2 DI KOTA TASIKMALAYA
}

\author{
Yanyan Bahtiar', Hj. Betty Suprapti ${ }^{2}$. \\ 1, 2, Dosen Jurusan Keperawatan Poltekkes Kemenkes Tasikmalaya
}

\begin{abstract}
ABSTRAK
Diabetes Melitus (DM) merupakan ancaman global dan serius sehingga perlu berbagai upaya untuk menanggulanginya secara dini. Teknik relaksasi hipnosis merupakan salah satu tindakan keperawatan yang diduga bisa mengendalikan kadar gula darah pasien DM. Penelitian ini bertujuan untuk mengetahui pengaruh terapi hipnosis terhadap kadar gula darah pasien DM tipe 2. Besaran sampel sebanyak 20 kelompok intervensi dan 20 kontrol. Desain penelitian menggunakan pendekatan quasi eksperimen dengan uji-t dan paried-t. Dalam kondisi hipnosis, stres dapat teratasi dengan sugesti positif sehingga secara tidak langsung hipofisis dapat dikendalikan. Dengan pengendalian hipofisis maka fungsi vital tubuh dapat terkontrol, peningkatan metabolism akibat stress dapat tercegah sehingga peningkatan kadar gula darahnya dapat terkendali. Setelah diberikan dua kali perlakuan terapi hypnosis pada kelompok intervensi, terjadi penurunan rerata kadar gula darah sebesar $33,6 \mathrm{mg} / \mathrm{L}$. Secara statistic terdapat perbedaan rata-rata kadar gula darah sebelum dan setelah terapi hipnosis pada kelompok intervensi $(\rho=0,000)$. Sedangkan pada uji beda antara kelompok intervensi dengan kontrol secara statistic tidak terdapat perbedaan yang signifikan $(\rho=0,642)$. Walaupun demikian rerata kadar gula darah kelompok intervensi setelah terapi hipnosis mempunyai selisih lebih tinggi dari kelompok kontrol. Bagi petugas kesehatan diharapkan dapat memberikan intervensi terapi hipnosis pada penderita DM selain terapi obat dan diet.
\end{abstract}

Kata Kunci : Diabetes Melitus, Terapi hipnosis, Sugesti, Stres.

\begin{abstract}
Diabetes mellitus (DM) is a global threat and serious so it is necessary efforts to mitigate them early. Hypnosis relaxation technique is one of the nursing actions that allegedly could control blood sugar levels diabetic patients. This study aims to determine the effect of hypnosis therapy on blood sugar levels of patients with DM type 2. Magnitude sample of 20 intervention and 20 control. The study design using quasi-experimental approach with t-test and paried-t. Having given twice hypnosis therapy treatment in the intervention group, there was a mean decrease in blood sugar levels by $33,6 \mathrm{mg} / \mathrm{L}$. Statistically there are differences in average blood sugar levels before and after the hypnosis therapy in the intervention group $(\rho=0.000)$. While the difference between the test group with the control intervention was not statistically significant differences $(\rho=0.642)$. Nevertheless, the average blood sugar levels after the intervention group hypnosis therapy have a higher marginof the control group. In hypnosis, stress can be resolved with a positive suggestion that indirectly pituitary can be controlled. With the pituitary controls the body's vital functions can be controlled, increased metabolism due to stress can be prevented so that the increase in blood sugar levels can be controlled. This research is expected to be useful as reference material management of DM type 2 patients, particularly in the control of stress or anxiety
\end{abstract}

Keywords : Diabetes Mellitus, Therapeutic hypnosis, Suggestion, Stress. 
Yanyan B., \& Hj. Betty S.,; Poltekkes Tasikmalaya; DM, Terapi hipnosis, Sugesti, Stres.

\section{PENDAHULUAN}

Diabetes Melitus (DM) di Indonesia merupakan ancaman serius bagi pembangunan kesehatan dan pertumbuhan ekonomi nasional. Penyakit ini penyebab kematian nomor 6 dari seluruh kematian pada semua kelompok umur (Depkes, 2012). Berdasarkan hasil Riset Kesehatan Dasar (Riskesdas) tahun 2007, Prevalensi penyakit DM di Jawa Barat sebesar 1,3\% (0,4\%-2,5\%) dan di Kota Tasikmalaya sebesar $0,7 \%$ (Depkes, 2008). Sedangkan menurut hasil pendataan dari Dinas Kesehatan Kota Tasikmalaya tahun 2012, penderita diabetes yang teridentifikasi berjumlah 547 orang (Dinkes Kota Tasikmalaya, 2012).

Pengendalian diabetes sangatlah penting dilaksanakan sedini mungkin; melakukan gaya hidup sehat, membiasakan olah raga, mengatasi stres, dan tidak merokok merupakan kebiasaan yang baik dalam pencegahan Diabetes Melitus.

Kondisi stres baik secara fisiologik maupun emosional dapat memberi dampak negatif terhadap pengendalian diabetes. Peningkatan hormon stres akan meningkatkan kadar gula darah. Dalam keadaan stres, pasien DM dapat mengubah pola kebiasaan yang baik, terutama dalam hal makan, latihan dan pengobatan (Brunner and Suddarth's, 2013). Berdasarkan hasil wawancara yang dilakukan peneliti pada 5 orang penderita $\mathrm{DM}$, semuanya mengatakan bahwa sejak mengetahui mempunyai penyakit DM sering merasa khawatir dan takut yang tidak menentu, apalagi kalau melihat penderita DM yang terkena luka di kaki dan sampai diamputasi. Salah seorang penderita juga mengatakan bahwa dirinya sangat terkekang dalam hidupnya, terutama dalam hal mengatur makanan atau diet.

Perawat secara profesional berperan dalam membantu pasien DM dalam mengendalikan gula darah, diantaranya adalah intervensi mengurangi kecemasan (Brunner and Suddarth's, 2013). Teknik relaksasi merupakan salah satu tindakan keperawatan yang bisa digunakan untuk mengubah pola perilaku. Secara fisiologis, relaksasi dapat menurunkan stres. Dengan relaksasi, hipotalamus akan mengatur dan menurunkan aktivitas sistem saraf simpatis (Brunner and Suddarth's, 2013).

Berdasarkan berbagai fenomena tersebut, penulis tertarik untuk melakukan penelitian guna menemukan teknik relaksasi yang lebih efektif dalam pengendalian gula darah pada penderita DM type 2. Terdapat beberapa teknik relaksasi dalam intervensi keperawatan, diantaranya relaksasi dengan pendekatan hipnosis. Hipnosis merupakan bagian dari human mind control system (Budi \& Rizali, 2010). Pakar keperawatan, Larkin dalam Anselmo (2005) menjelaskan bahwa hipnosis merupakan sebuah proses komunikasi terapeutik dan penyadaran perilaku dalam kontek hubungan terapeutik. Sugesti hipnosis dapat meningkatkan kerjasama pasien dan kenyamanan pasien dalam perawatan, termasuk mengatasi stress dan memperbaiki pola perilaku. Tujuan penelitian ini adalah untuk mengetahui pengaruh terapi hipnosis terhadap kadar gula darah pada pasien DM tipe 2 di Kota Tasikmalaya. Penelitian ini diharapkan dapat bermanfaat menjadi tambahan intervensi dalam pengelolaan pasien DM. Hipotesis penelitian yang diujikan adalah $\left(\mathrm{H}_{1}\right)$ ada pengaruh terapi hipnosis terhadap kadar gula darah pada pasien DM tipe 2 .

\section{METODE PENELITIAN}

Penelitian ini didesain menggunakan quasi-eksperimen dengan tipe PretestPosttest Group Design. Populasi adalah semua masyarakat yang menderita diabetes di wilayah kerja Dinas Kesehatan Kota Tasikmalaya sebanyak 547 orang. Ukuran sampel didapatkan dari rumus pengambilan sampel dengan variabel tidak berpasangan dengan menggunakan rumus; (Dahlan, 2006).

$$
n=2\left[\frac{\sigma\left(Z_{1-\alpha / 2}+Z_{1-\beta}\right)}{\left(\mu_{1}-\mu_{2}\right)}\right]^{2}
$$

Ukuran sampel penelitian sebanyak 20 kelompok intervensi dan 20 kontrol. Teknik sampling dalam penelitian ini adalah convenient sampel yaitu pengambilan sampel 
Yanyan B., \& Hj. Betty S.,; Poltekkes Tasikmalaya; DM, Terapi hipnosis, Sugesti, Stres.

pada semua pasien yang ditemui dan sesuai dengan kriteria inklusi berdasarkan periode tertentu. Sampel diperoleh dari populasi berdasarkan kriteria inklusi yaitu klien dengan diagnosa DM tipe 2 di wilayah Dinas Kesehatan Kota Tasikmalaya; sedang mendapatkan terapi dari Puskesmas atau klinik pratama; umur antara 25-65 tahun; dapat memahami bahasa Indonesia; dapat berkomunikasi; bersedia berpartisipasi dalam penelitian dengan menandatangi informed consent.

Teknik analisis terdiri dari uji normalitas data, uji varians, uji univariat dan uji bivariat. Pengolahan data bivariat menggunakan analitik pendekatan quasi eksperimen dengan uji-t dan paried-t.

\section{HASIL PENELITIAN}

\section{Star Point}

Tabel 1. Perbedaan rata-rata kadar gula darah pasien DM tipe 2 sebelum terapi hipnosis antara kelompok intervensi dengan kelompok kontrol, $\left(n_{1}=n_{2}=20\right)$.

\begin{tabular}{lcccc}
\hline \multicolumn{2}{c}{ Variabel } & Gula Darah & SD & $\rho$-value \\
\hline $\begin{array}{l}\text { Kadar Gula } \\
\text { Darah }\end{array}$ & Intervensi & $349,10 \mathrm{mg} / \mathrm{L}$ & 137,61 & 0,894 \\
\cline { 2 - 4 } & Kontrol & $355,00 \mathrm{mg} / \mathrm{L}$ & 141,01 & \\
\hline
\end{tabular}

Hasil uji $T$-test diperoleh nilai $\rho=0,894$. Hal ini menunjukkan bahwa nilai $\rho>0,05$ berarti tidak ada perbedaan yang bermakna antara kadar gula darah antara kelompok intervensi dengan kelompok kontrol di awal

\section{Analisis Univariat}

a. Kadar gula darah pasien DM Tipe 2 kelompok intervensi sebelum dan setelah terapi hipnosis.

Tabel 2. Distribusi kadar gula darah pasien DM Tipe 2

Kelompok intervensi sebelum dan setelah terapi hipnosis, $(n=20)$.

\begin{tabular}{cccccc}
\hline $\begin{array}{c}\text { Waktu } \\
\text { Perlakuan }\end{array}$ & Variabel & Mean & SD & Min - Maks & 95\% Cl \\
\hline \multirow{2}{*}{ Hari ke-1 } & Sebelum Hipnosis & 349,10 & 137,61 & $177-590$ & $284,8-413,5$ \\
\cline { 2 - 6 } & Setelah Hipnosis & 328,15 & 125,30 & $160-549$ & $269,5-386,8$ \\
\hline \multirow{2}{*}{ Hari ke-3 } & Sebelum Hipnosis & 339,60 & 135,12 & $170-585$ & $276,4-402,8$ \\
\cline { 2 - 6 } & Setelah Hipnosis & 315,50 & 120,70 & $162-538$ & $259,0-371,9$ \\
\hline
\end{tabular}

Rata-rata kadar gula darah pasien DM Tipe 2 kelompok intervensi sebelum dan setelah terapi hipnosis dapat dilihat pada tabel 2. Rata-rata kadar gula darah setelah terapi hipnosis lebih rendah dari sebelum terapi hipnosis atau terjadi penurunan. Pada hari pertama intervensi hipnosis terjadi perubahan kadar gula darah setelah diberikan terapi. Hasil uji tersebut dapat disimpulkan bahwa kelompok intervensi dan kelompok kontrol mempunyai star point kadar gula darah yang relatif sama. 
Yanyan B., \& Hj. Betty S.,; Poltekkes Tasikmalaya; DM, Terapi hipnosis, Sugesti, Stres.

b. Kadar gula darah pasien DM Tipe 2 kelompok kontrol

Tabel 3. Distribusi kadar gula darah pasien DM Tipe 2 kelompok kontrol $(n=20)$.

\begin{tabular}{ccccc}
\hline Variabel & Mean & SD & Min - Maks & 95\% Cl \\
\hline Kadar Gula Darah Hari ke-1 & 355,00 & 141,00 & $160,0-590,0$ & $289-421$ \\
\hline Kadar Gula Darah Hari ke-3 & 334,70 & 137,96 & $142,0-590,0$ & $270-399$ \\
\hline
\end{tabular}

Rata-rata kadar gula darah pasien DM Tipe 2 kelompok control pada hari pertama dan hari ketiga kunjungan dapat dilihat pada tabel 3. Pada hari ketiga atau kunjungan kedua terjadi penurunan kadar gula darah dengan selisih sebesar $20,3 \mathrm{mg} / \mathrm{L}$.

\section{Analisis Bivariat}

a. Perbedaan rata-rata kadar gula darah sebelum dan setelah terapi hipnosis pada pasien DM Tipe 2 kelompok intervensi

Tabel 4. Perbedaan rata-rata kadar gula darah sebelum dan setelah terapi hipnosis pada pasien DM Tipe 2 kelompok intervensi, $(n=20)$.

\begin{tabular}{ccccc}
\hline Intervensi & $\begin{array}{c}\text { Rata-rata Kadar } \\
\text { Gula Darah }\end{array}$ & SD & 95\% Cl & $\boldsymbol{\rho}$-value \\
\cline { 1 - 3 } Hari ke-1 & 349,10 & 137,61 & $17,63-49,57$ & 0,000 \\
\cline { 1 - 3 } Hari ke-3 & 315,50 & 120,70 & & \\
\hline
\end{tabular}

Hasil analisis data didapatkan bahwa kadar gula darah pada kelompok intervensi turun $33,6 \mathrm{mg} / \mathrm{L}$ setelah mendapatkan terapi hipnosis pada hari ketiga. Berdasarkan hasil uji paried-t diperoleh nilai signifikansi $\rho=0,000$ $(\rho<0,05)$, berarti $\mathrm{H}_{0}$ ditolak atau terdapat perbedaan rata-rata kadar gula darah sebelum dan setelah terapi hipnosis pada pasien DM tipe 2 kelompok intervensi.

b. Perbedaan rata-rata kadar gula darah pada pasien DM tipe 2 setelah terapi hipnosis antara kelompok intervensi dengan kelompok kontrol.

Tabel 5. Perbedaan rata-rata kadar gula darah pasien DM tipe 2 setelah terapi hipnosis kedua antara kelompok intervensi dengan kontrol, $\left(n_{1}=n_{2}=20\right)$.

\begin{tabular}{lccccc}
\hline \multicolumn{2}{c}{ Variabel } & GulaDarah & SD & 95\% Cl & $\rho$-value \\
\hline Kadar Gula & Intervensi & 315,50 & 120,70 & $\begin{array}{c}-102,2- \\
63,8\end{array}$ & 0,642 \\
\cline { 2 - 4 } Darah hari ke-3 & Kontrol & 334,70 & 137,96 & & \\
\hline
\end{tabular}

Hasil analisis data didapatkan bahwa kadar gula darah setelah terapi hipnosis pada kelompok intervensi mempunyai selisih sebesar 19,2 mg/L dari kelompok kontrol. Berdasarkan hasil uji t berpasangan diperoleh nilai signifikansi $\rho=0,642(\rho>0,05)$, berarti $\mathrm{H}_{0}$ tidak ditolak yaitu tidak terdapat perbedaan yang signifikan rata-rata kadar gula darah setelah terapi hipnosis antara kelompok intervensi dengan kelompok kontrol. 
Yanyan B., \& Hj. Betty S.,; Poltekkes Tasikmalaya; DM, Terapi hipnosis, Sugesti, Stres.

\section{PEMBAHASAN}

Rerata kadar gula darah sebelum diberikan terapi hipnosis pada kelompok intervensi adalah $349,10 \mathrm{mg} / \mathrm{dL}$. Setelah diberikan terapi hipnosis pertama rerata kadar gula darah menurun menjadi $328,15 \mathrm{mg} / \mathrm{dL}$. Pada kunjungan kedua atau pada hari ketiga rerata kadar gula darah kembali naik menjadi $339,60 \mathrm{mg} / \mathrm{dL}$ dan setelah diberikan terapi hipnosis hari tersebut (hari ketiga kunjungan kedua) rerata kadar gula darah menurun menjadi $315,50 \mathrm{mg} / \mathrm{dL}$, sehingga didapatkan penurunan kadar gula darah sebesar 33,6 $\mathrm{mg} / \mathrm{L}$ pada terapi hipnosis terakhir. Pada kelompok kontrol juga terjadi penurunan kadar gula darah antara hari pertama kunjungan dengan hari ketiga kunjungan sebesar $19,2 \mathrm{mg} / \mathrm{L}$, lebih rendah dibanding dengan yang mendapat intervensi hipnosis.

Penelitian ini sejalan dengan penelitian yang dilakukan oleh Kuswandi (2007), yaitu melakukan penelitan mengenai perbandingan kadar gula darah pasien DM tipe 2 yang melakukan relaksasi dengan yang tidak melakukan relaksasi. Hasilnya menunjukkan terjadi penurunan kadar gula darah rata-rata sesudah relaksasi dari $289 \mathrm{mg} / \mathrm{dL}(\mathrm{SD}=8,96$ $\mathrm{mg} / \mathrm{dL}$ ) menjadi $236 \mathrm{mg} / \mathrm{dL}(\mathrm{SD}=23,88 \mathrm{mg} / \mathrm{dL})$ atau penurunan sebesar $53 \mathrm{mg} / \mathrm{dL}$. Secara uji statistik relaksasi dapat menurunkan kadar gula darah pasien DM tipe 2 secara signifikan $(\alpha=0,000)$. Pada penelitian ini peneliti memberikan perlakuan relaksasi juga tetapi dengan metode yang berbeda yaitu dengan teknik terapi hipnosis.

Terapi hipnosis pada intinya adalah memberikan sugesti pada pikiran bawah sadar klien sehingga fikiran dan fisik klien manjadi rilek dan segar kembali. Hasil penelitian telah menunjukkan, bahwa relaksasi dengan terapi hipnosis bagi pasien diabetes tipe 2 mempengaruhi penurunan kadar gula darah dibandingkan dengan yang tidak melakukannya, walaupun secara statistik tidak terlalu signifikan. Relaksasi diketahui dapat membantu menurunkan kadar gula darah pada pasien diabetes karena dapat menekan pengeluaran hormon-hormon yang dapat meningkatkan kadar gula darah, yaitu epinefrin, kortisol, glukagon, adrenocorticotropic hormone (ACTH), kortikosteroid, dan tiroid. Dalam keadaan stress, epinefrin beraksi pada hati meningkatkan konversi glikogen menjadi glukosa.

Kortisol memiliki efek meningkatkan metabolisme glukosa, sehingga asam amnino, laktat, dan pirufat diubah di hati menjadi glukosa (glukoneogenesis) akhirnya menaikkan kadar gula darah. Glukagon meningkatkan kadar gula darah dengan cara mengkonversi glikogen di hati (bentuk karbohidrat yang tersimpan pada mamalia) menjadi glukosa, sehingga gula darah menjadi naik. ACTH dan glukokortikoid pada korteks adrenal dapat meningkatkan kadar gula darah dengan cara meningkatkan pembentukan glukosa baru oleh hati. ACTH dan glukokortikoid juga meningkatkan lipolysis dan katabolisme karbohidrat (Brunner and Suddarth's, 2013).

Vasodilatasi juga dirangsang oleh stimulasi gelombang alfa otak yang berdampak pada keseimbangan sistem saraf simpatis-parasimpatis, relaksasi otot selama hipnosis, peningkatan konsumsi oksigen di paru dan peningkatan pemanfaatan oksigen jaringan berdampak pada tonus vaskuler (Budi \& Rizali, 2010).

Hipnosis dapat juga memainkan peranan penting dalam menjaga kesehatan jantung serta membantu pemulihan dari berbagai penyakit jantung. Ketika memasuki pase trance, terjadi suatu pergeseran sistem saraf otonom dari simpatik ke control saraf parasimpatis. Ketika sistem saraf parasimpatis mendominasi penurunan denyut jantung, maka akan mengurangi beban pada sistem kardiovaskular (Bryant \& Mabbutt, 2006).

Hipnosis dimasukan dalam terapi nonfarmakologi yang bekerja melakukan komunikasi dengan bagian tubuh lain seperti hipothalamus dan sistem saraf simpatis dan parasimpatis (Bryant \& Mabbutt, 2006). Kelenjar hipofisis adalah kelenjar kecil yang melekat pada hipothalamus, menyuplai hormon yang mengontrol fungsi vital. Kelenjar hipofisis menghasilkan hormon yang dapat 
Yanyan B., \& Hj. Betty S.,; Poltekkes Tasikmalaya; DM, Terapi hipnosis, Sugesti, Stres.

digunakan untuk beradaptasi terhadap stres (Potter \& Pery, 2006). Dalam kondisi hipnosis, stres dapat teratasi dengan sugesti positif sehingga secara tidak langsung hipofisis dapat dikontrol. Dengan kontrol hipofisis maka fungsi vital tubuh dapat terkontrol, peningkatan metabolisme akibat stress dapat terkendali dan gula darah pun dapat terkontrol.

Teknik relaksasi dan hipnosis memungkinkan terjadinya asupan oksigen yang adequat. Oksigen sangat dibutuhkan oleh tubuh untuk berlangsungnya metabolisme yang optimal. Salah satu organ vital yang memerlukan suplai oksigen adalah jantung, karena kebutuhan oksigen sebagai faktor utama dalam pengaturan lokal aliran darah koroner. Aliran darah di sistem koroner hampir sebanding dengan kebuthan oksigen otot jantung. Biasanya sekitar $70 \%$ oksigen di dalam arteri koroner dipindahkan selagi darah mengalir melalui otot jantung. Gangguan pada jantung atau sistem kardiovaskuler salah satu pencetusnya adalah stres, baik secara fisik maupun psikis.

Stres memiliki efek nyata pada sistem kardiovaskular dan metabolisme. Stres kronis dapat mengakibatkan tekanan darah tinggi, aterosklerosis, stroke, serangan jantung, gangguan sistem kardiovaskular dan peningkatan metabolism dalam tubuh. Perlu diingat bahwa stres adalah penyebab utama yang merangsang pengeluaran hormonhormon yang dapat meningkatkan kadar gula darah.

Teknik relaksasi dapat membantu mengurangi stres yang dapat berpengaruh pada peningkatan metabolisme. Meditasi, latihan pernapasan dan teknik lain dapat membantu untuk menurunkan tingkat zat kimia oksidatif dalam darah, yang pada gilirannya menurunkan risiko aterosklerosis sehingga dapat mempertahankan tekanan darah dalam batas normal. Salah satu cara yang telah diterima dan mendapat perhatian lebih dalam mengatasi DM tipe 2 adalah dengan menggunakan hipnoterapi (terapi hipnosis) atau NLP (neuro linguistic programme). Hipnosis menimbulkan respon fisiologis seperti penurunan denyut nadi, penurunan konsumsi oksigen, penurunan kecepatan pernapasan, penurunan tekanan darah dan penurunan tegangan otot. Selain itu, yang utamaakan berdampak terhadap respon psikologis yaitu menurunkan stres dan kecemasan (Grossman, 2010).

Anselmo (2005) mengungkakan bahwa terapi hipnosis telah digunakan oleh perawat dalam perawatan pada pasien terminal, palliative care, perawatan rumah (home care) dan perawatan pasien kritis. Terapi hypnosis juga sangat baik digunakan pada unit luka bakar, onkologi, kebidanan, kedokteran dan unit operasi.

Hipnosis merupakan sesuatu yang ilmiah, bukan magis, klenik, ataupun mistis. Hipnosis merupakan bagian dari kemampuan mind control learning, yaitu kemampuan mengendalikan gelombang otak atau kemampuan mengendalikan pola berpikir dalam memasukialam pikir bawah sadar dan kembali ke alam pikir sadar pada saat berada dalam keadaan terhipnosis (Budi \& Rizali, 2010).

Hipnosis merupakan bagian dari terapi kognitif. Hipnosis sebagai terapi kognitif akan mempengaruhi organ lain melalui pengaturan sistem endokrin dan system saraf baik saraf simpatis maupun parasimpatis. Terapi kognitif dapat mempengaruhi proses fisiologis, psikologis, sosial, perilaku dan spiritual. Terapi kognitif sering disebut sebagai restrukturisasi kognitif, karena bertujuan untuk mengubah atau merestrukturisasi distorsi pola pikir yang menyebabkan stres (Shor \& Federman, 2005).

Terapi hipnosis merupakan salah satu bagian dalam ruang lingkup terapi komplementer (Depkes, 2008). Terapi komplementer sekarang ini terus berkembang sejalan dengan perkembangan kehidupan manusia yang menginginkan pilihan terbaik bagi kesehatan tubuhnya. Seperti yang terjadi di sebuah negara berkembang yaitu Negara Nigeria. Osamor dan Owumi (2010) mengatakan bahwa penggunaan obat alternatif dan terapi komplementer (complementary and alternative medicine) sudah sangat umum dilakukan oleh penderita 
Yanyan B., \& Hj. Betty S.,; Poltekkes Tasikmalaya; DM, Terapi hipnosis, Sugesti, Stres.

diabetes di komunitas perkotaan Negara Nigeria.

Terapi alternatif dan komplementer di Indonesia sudah mulai diperhatikan yaitu dengan telah terbitnya Peraturan Menteri Kesehatan RI Nomor 1109 Tahun 2007 tentang penyelenggaraan pengobatan komplementer-alternatif di fasilitas pelayanan kesehatan (Depkes, 2008). Seiring dengan perkembangnya, terapi komplementer mulai banyak dikembangkan dan mulai berdampingan dengan pengobatan modern/konvensional.

Pelayanan komplementer-alternatif dapat dilaksanakan secara sinergi, terintegrasi dan mandiri di fasilitas pelayanan kesehatan. Pengobatan itu harus aman, bermanfaat, bermutu dan dikaji institusi berwenang sesuai dengan ketentuan yang berlaku (Depkes, 2007). Fasilitas pelayanan kesehatan yang dapat digunakan untuk melaksanakan sinergi pelayanan medik pengobatan komplementer alternatif adalah rumah sakit, praktek swasta dan juga puskesmas. Sedangkan jenis atau ruang lingkup terapi komplementer yang dapat diberikan di sarana pelayanan kesehatan sangat beragam dan komplek.

Salah satu dari jenis pelayanan pengobatan komplementer-alternatif berdasarkan Permenkes RI, Nomor 1109/ Menkes/ Per/ 2007 adalah intervensi tubuh dan pikiran: hipnoterapi, mediasi, penyembuhan spiritual, doa dan yoga (Depkes, 2008). Menurut peraturan tersebut pelayanan pengobatan komplementeralternatif dapat diberikan oleh dokter, dokter gigi dan tenaga kesehatan lainnya seperti perawat yang memiliki pendidikan terstruktur dalam bidang terapi komplementer-alternatif.

Perawat merupakan profesi kesehatan yang merawat pasien dengan melakukan pendekatan secara holistik (bio, psiko, sosio,

\section{KESIMPULAN}

Rerata kadar gula darah setelah terapi hypnosis lebih rendah dari sebelum terapi hipnosis. Secara statistic terdapat perbedaan rata-rata kadar gula darah sebelum dan setelah terapi hipnosis pada pasien DM tipe 2 kelompok intervensi. Rerata kadar gula darah kultural, spiritual). Terapi hipnosis dianggap sebagai terapi dengan pendekatan holistik karena berusaha menyembuhkan pasien dengan memandang dari berbagai sudut dan beraneka aspek kehidupan pasien. Menurut salah seorang pakar keperawatan, Larkin dalam Anselmo (2005), mengatakan bahwa hipnosis merupakan sebuah proses komunikasi terapeutik dan penyadaran perilaku dalam konteks hubungan terapeutik.

Kajian ilmiah mengenai terapi komplementer perlu terus dikembangkan di dunia keperawatan, terutama di ranah keperawatan komunitas. Selain itu, untuk menunjang terapi ini diperlukan penelitian dan pelatihan yang berkelanjutan, sehingga perawat selain menggali keilmuan klinik diharapkan juga dibekali dengan ilmu penelitian dan keterampilan yang cukup memadai.

Berdasarkan penelitian yang sudah dilakukan oleh peneliti mengenai perbedaan kadar gula darah sebelum dan setelah terapi hipnosis pada klien DM tipe 2 di wilayah Kota Tasikmalaya, menunjukan bahwa terapi komplementer keperawatan "terapi hipnosis" pada pasien DM tipe 2 memiliki pengaruh yang signifikan dalam penurunan kadar gula darah pasien tersebut. Implikasi penelitian pada ilmu keperawatan yaitu memberikan gambaran bahwa penggunaan terapi nonfarmakologi hipnosis dapat membantu menurunkan kadar gula darah pada klien DM tipe 2.

Peneliti merekomendasikan pada institusi pendidikan keperawatan untuk memasukan terapi komplementer ke dalam kurikulum pendidikan. Bagi petugas kesehatan direkomendasikan supaya terapi hipnosis menjadi salah satu intervensi keperawatan khususnya untuk pengelolaan pasien DM.

setelah terapi hipnosis pada kelompok intervensi mempunyai selisih lebih tinggi dari kelompok kontrol. Tetapi secara statistic tidak terdapat perbedaan yang signifikan rata-rata kadar gula darah setelah terapi hipnosis antara kelompok intervensi dengan kelompok kontrol. 
Yanyan B., \& Hj. Betty S.,; Poltekkes Tasikmalaya; DM, Terapi hipnosis, Sugesti, Stres.

\section{REFERENSI}

Anselmo, J., (2005). Relaxation: the first step to restore, renew, and self-heal. In Dossey B.M., Keegan L., \& Guzzeta C.E. (Eds). Holistic nursing a handbook for practice. 4.Ed. The United States: Jones and Bartlett Publishers, Inc.

Bryant, M.,\& Mabbutt, P., (2006). Hypnotherapy for dummies. Chichester, West Sussex, England: John Wiley \& Sons, Ltd.

Budi, P.P., \&Rizali, E., (2010). Cara cepat menggusasi hypno healing. Yogyakarta: leutika.

Brunner \& Suddarth's., (2013). Keperawatan Medikal Bedah. Jakarta: EGC.

Dahlan, M.S., (2006). Besar sampel dalam penelitian kedokteran dan kesehatan. Jakarta: PT. Arkans.

Depkes, (2008). Laporan Riskesdas Jawa Barat Tahun 2007. Jakarta: Depkes.RI , (2012). Kemitraan Kementrian Kesehatan dengan Sanofi Group. Diunduh pada tanggal 30 Januari 2013 dari www.promkes.depkes.go.id

Dinkes Kota Tasikmalaya, (2012). Data laporan program perkesmas Dinas
Kesehatan Kota Tasikmalaya. Tidak dipublikasikan.

Grossman, (2010). Hypnosis for hypertension. Makalah tidak dipublikasikan

Kuswandi, (2007). Perbandingan kadar gula darah pasien DM tipe 2 yang melakukan relaksasi dengan yang tidak melakukan relaksasi di Kota Tasikmalaya. Laporan tesis Magister Keperawatan Universitas Indonesia, Tidak dipublikasikan.

Potter, P.A. \& Perry, A.G., (2005). Buku Ajar Fundamental Keperawatan: Konsep Prosesdan Praktek, Alih Bahasa: Renata, K., dkk. Edisi 4, Volume: 1, Jakarta: EGC

Shor E.S., \& Federman C.S., (2005). Cognitive Therapy. In Dossey B.M., Keegan L., \& Guzzeta C.E., Holistic nursing a handbook for practice. $4^{\text {th }} \mathrm{Ed}$. The United States: Jones and Bartlett Publishers, Inc.

Osamor, P.E., \& Owumi, B.E., (2010). Complementary and alternative medicine in the management of hypertension in an urban Nigerian community. BMC Complementary and Alternative Medicine, 10,36: 1 - 9., doi: 10.1186/1472-6882-10-36. 